Man and Nature

L'homme et la nature

\title{
Liberty is My Due: Don Juan and Free Thought in the ancien régime
}

\section{Richard W. Bevis}

Volume 8, 1989

URI : https://id.erudit.org/iderudit/1012591ar

DOI : https://doi.org/10.7202/1012591ar

Aller au sommaire du numéro

Éditeur(s)

Canadian Society for Eighteenth-Century Studies / Société canadienne d'étude du dix-huitième siècle

ISSN

0824-3298 (imprimé)

1927-8810 (numérique)

Découvrir la revue

Citer cet article

Bevis, R. W. (1989). Liberty is My Due: Don Juan and Free Thought in the ancien régime. Man and Nature / L'homme et la nature, 8, 1-8.

https://doi.org/10.7202/1012591ar

Copyright (C Canadian Society for Eighteenth-Century Studies / Sociéte canadienne d'étude du dix-huitième siècle, 1989
Ce document est protégé par la loi sur le droit d'auteur. L'utilisation des services d'Érudit (y compris la reproduction) est assujettie à sa politique d'utilisation que vous pouvez consulter en ligne.

https://apropos.erudit.org/fr/usagers/politique-dutilisation/ 


\section{Liberty is My Due: Don Juan and Free Thought in the ancien régime}

As risky as generalizations about a mythic figure with numerous avatars are apt to be, it is safe to assert that in the seventeenth and eighteenth centuries Don Juan was used primarily as a character obsessed with liberty of behaviour, with freedom from the restrictions that most men accept. Dramatists commonly portrayed him as one who 'follows his own instincts without regard to the common, statute or canon law. ${ }^{\prime 1}$ As a character in eighteenth-century puppet shows, Don Juan foreshadowed the moustache-twirling villain of Victorian melodrama who tries to be a law unto himself - and is, until thwarted by a greater strength. Yet the hubristic aspects of his quest make Don Juan always potentially tragic material, a symbol of that part of us that rebels not only against society's restraints but even against the parameters of the human condition, and help to account for his enduring fascination. Don Juan wants to operate within society, yet demands to be exempted from, among other things, the oaths that bind us to one another and the codes that govern - or perhaps constitute - society; in Rousseauvian terms, he wants to be social without a contract. We in society cannot accept this demand: at some level we grasp the central paradox of law and religion, that one must accept some structures that confine certain of one's own and others' impulses in order to achieve and release a modicum of individual liberty. But we can understand (and vicariously enjoy, before punishing) Don Juan's impulse to have it both ways.

If this conclusion seems a trifle obvious, it has certainly not always been the one drawn by readers of the story. The popular Don Juan is, of course, a clever, perfidious womanizer, a 'triumph of sensuality,' though the view taken by Byron and Shaw was that Don Juan is more pursued than pursuer. (Apropos, Giacomo Casanova, who is said to have worked on the libretto for Don Juan, claimed, 'I continued to be the dupe of women until I was sixty.') $)^{2}$ The Freudian Wilhelm Stekel, possibly drawing on Søren Kirkegaard's discussion in Either/Or, saw Don Juan as a closet homosexual, unsatisfied by women, and using his affairs to deflect the knowledge that he is attracted to his man- 
servant. Another Freudian, Otto Rank, argued that Don Juan is driven by guilt arising from an Oedipus complex. Nineteenth-century Europeans variously interpreted Don Juan as a Dantesque seeker after the ideal, as an Adam looking for a pre-lapsarian Eve, as Satan, a bored rake or a foolish fop, etc. ${ }^{3}$ But those are later chapters: I am concerned here with the Don Juan of the ancien régime, whose passion is to be freed from the rules by which most of us feel bound, and yet to remain among us, as a predator.

Unlike Hamlet and Don Quixote (rather more like Faust), Don Juan was not definitively portrayed in the work that introduced him. ${ }^{4}$ By general consent that was Tirso de Molina's El Burlador de Sevilla y convidado de piedra, a problematical text which may have been written by 1615 but was not published until 1630; a sharply variant version, Tan largo me lo fiáis, is undated. If, as Leo Weinstein says, Tirso's version contains the germ of all future Don Juans, it is by being suggestive and sketchy, not definitive. Tirso provides a quick outline of the adventures of a playboy prankster 'whose greatest pleasure is to trick a woman and leave her without honor,' as the Don says in his most (or only) reflective moment ['el mayor/Gusto que en mi puede haber,/Es burlar una mujer/Y dejarla sin honor']. ${ }^{5}$ Tirso's successors were never willing to let the question of motivation stop there, however: the man who can defy the Stone Guest so heroically ('I'm full of life and strength ['Tengo brio/Y corazon en las carnes'] ... I would eat if you fed me all the vipers of hell' ['Si me dieres aspid, aspides/Cuantos el infierno tiene']) $m u s t$ be more than a mere 'trickster. ${ }^{\prime 6}$ The story of this raging sinner's crime and punishment has proved irresistible, but none of the many writers who have found the character provocative has felt limited to Tirso's reading of it.

Judging by the numbers and languages of the works about him, Don Juan has remained primarily a phenomenon of Continental Europe; the English 'rake,' while clearly a related figure, has a distinct development and somewhat different characteristics. But one of the earliest rakes, Mirabel in John Fletcher's The Wild-Goose Chase, is very Don Juanesque, and since the play dates from around 1620, he could actually be our first 'Don Juan.' As shameless, selfish and faithless a fornicator as any of them, Mirabel even keeps a list of his amorous triumphs to show a troublesome woman:

Look over all these ranks; all these are women,

Maids, and pretenders to maidenheads; these are my conquests;

All these I swore to marry, as I swore to thee .... .

Mirabel's highest value is freedom of action: 'liberty is my due,' he insists, 'I must not lose my liberty.' His anarchic side is, predictably, well 
developed; he is 'a loose and strong defier of all order,' with a dark underlying stratum of misogyny that crops out in many a Don Juan:

... there was never yet man hoped for

Either constancy or secrecy from a woman [he claims,]

... Whate'er we say or swear, they being reprobates,

Out of the state of faith, we are clear of all sides ... .?

Of course Mirabel differs sharply from Don Juan in that he does not need to chase his quarry over garden walls and into nunneries - the women come to him in fashionable salons - and instead of going to Hell he is tricked into marriage. (In 1821, in a letter to the publisher of his Don Juan, Byron claimed that he had not decided whether to let his hero 'end in Hell, or in an unhappy marriage, not knowing which would be the severest. The Spanish tradition says Hell: but it is probably only an Allegory of the other state.' $)^{8}$

Like Fletcher's Mirabel, Molière's Dom Juan (1665) declares, 'J'aime la liberté en amour ${ }^{\prime 9}$ but Molière shows the larger pattern of belief, or non-belief, of which sexual promiscuity is seen to be a part. It is in Molière's version, already the fifth or sixth, that Don Juan first becomes fully self-conscious, capable of articulating his motives - as if he has now had time to understand himself. Molière presents him as a libertin in the early seventeenth-century sense of religious sceptic, free-thinker, to which that of sexual profligate was soon added.10 Pressed for his beliefs, Dom Juan replies, with a play on 'Dieu': 'Je crois que deux et deux sont quatre.'11 This whiff of Cartesian rationalism is part of the prevalent air of hetorodoxy hanging about the Dom, who has raised sexual infidelity to a philosophical principle: 'we're obliged by Nature' to seek 'Variety', he argues ['la nature nous oblige ... tout le plaisir de l'amour est dans le changement'].12 'Nature' is, so to speak, his 'God-word,' as in, 'I have a natural penchant for abandoning myself to everything that attracts me' ['J'ai une pente naturelle à me laisser aller à tout ce qui m'attire'] ${ }^{13}$ And, he might add, he feels that he is entitled to possess whatever attracts him. As Dryden would later write, of political liberty, 'What fools our fathers were, if this be true.'

Molière also develops Don Juan's servant into his master's most knowing critic and a representative of the disapproving element in the audiences. Sganarelle tells Gusman that Dom Juan is 'the greatest Libertine that the Earth ever bore ... an Heretick, that believes neither heaven nor Hell' ['le plus grand scélérat que la terre ait jamais porté ... un hérétique, qui ne croit ni Ciel, ni Enfer']. ${ }^{14}$ Thus the militantly orthodox tone of the finale is now adumbrated from the beginning, for this speech appears in the first scene. Molières's tactic was not, however, 
sufficient to allay the Church's suspicions about the kinds of materials presented in the play and its likely effect on audiences.

For Restoration Englishmen, the advocate of freethinking materialism was the Thomas Hobbes of Leviathan (1651); an egregious libertine such as the Earl of Rochester seemed, to his enemies, simply a living embodiment of Hobbes's principles. The most significant English treatment of Don Juan before Byron, Thomas Shadwell's The Libertine (1675), makes over the dashing Spanish cavalier into a ferocious caricature of a Hobbesian, guilty of 'Some thirty Murders, Rapes innumerable, frequent Sacrilege, Parricide. ${ }^{\prime 15}$ By the play's end, he has added six more murders, several rapes and untold sacrilege. (Don John is especially proud of 'a Noble and Heroick Rape' which he committed in a church.) Like most other Don Juans when pressed about their polygamy, this one insists on his right to the freedom he deems 'natural':

Since Liberty, Nature for all has design'd,

A pox on the Fool who to one is confin'd. ${ }^{16}$

In an original and ironic touch, however, Shadwell has Don John attack free will and espouse what would certainly have been seen as Hobbes's brand of determinism: 'How can the Will be free, when the understanding, / In which the Will depends, cannot be so?' he asks the old hermit. ${ }^{17}$ The liberty of action that he claims, then, is based not on the freedom of his will but on the 'necessity' of his molecules. If others do not act as he does, it must be because they are not constrained to; their imperatives are different. At the last, pressed by the Statue to repent, Don John replies simply, 'Cou'dst thou bestow another heart on me, I might; but with this heart I have, I cannot. ${ }^{18}$ His whole character - mind, will, heart - is an irresistible primary drive, the central given of his earthly existence. Don John would subscribe to Blake's 'Those who restrain desire, do so because theirs is weak enough to be restrained' (in The Marriage of Heaven and Hell). His desires are too strong to be curbed; they demand satisfaction. Through a biological determinism with theological ramifications, he is paradoxically forced to be free, to be libertin.

The alleged disappearance or submergence of the Don Juan motif during the eighteenth century is one of the clichés of literary history, ${ }^{19}$ though the well-known story continued to be performed in several versions on the legitimate stages of England and Europe and in pantomimes or harlequinades at the fairs. Perhaps authors of the Enlightenment thought the tale's possibilities had been exhausted, or judged that neither the ferocity of Don Juan nor the harshness of his punishment was likely to please the members of the more polished 
and permissive societies for which they wrote. Much of the freedom of belief and behaviour that the Don Juans of the seventeenth century had clamoured for was available to their eighteenth-century successors without half the fuss, at least in Paris and London.

As social conditions changed around 1700 , so did the codes men lived by and consequently the characters they drew. The 'new libertine ideals' of men such as St. Evremond in France and Congreve in England were 'moderate pleasure, retirement, love of art and gardens, scepticism, and refinement of manners,' even control of the passions: they were epicureans, aesthetes 'making an art of life. ${ }^{20}$ Don Juan gave way, for a time, to the rake and the roué. Lawrence Stone's massive argument (in The Family, Sex and Marriage in England 1500-1800) that the eighteenth century was when the modern family evolved its close affective bonds would suggest, however, that the libertine, especially the adulterer, would have been seen as an increasingly serious social threat during that period. There was a tendency, especially in England, for the literary rake to turn out to be good-natured at bottom, hence reformable; for every Lovelace or Valmont there are a dozen Tom Joneses and Charles Surfaces, excellent family men at last. Don Juan's lifelong campaign against any limits to his freedom was for the most part replaced by a consensus that the rake was probably just sowing wild oats, a phase he would pass through; the merest touch of good sense, good feeling, or a good woman was usually sufficient to snap him out of it. Stone Guests were uncalled for.

It can hardly have been an accident that da Ponte and Mozart reverted to the original Don Juan story in 1787, virtually on the eve of the French Revolution, when 'freedom' was a broad and pressing concern across the Old and New Worlds. Englishmen were establishing Sierra Leone as a refuge for freed black slaves, denouncing slavery in Parliment, and forming the Committee for Abolishing the Slave Trade; Americans were drafting a Constitution to 'secure the Blessings of Liberty to ourselves and our Posterity.' The debate over the perils and possibilities of freedom reached the stages on both sides of the Channel. Playwrights including Holcroft in England and Beaumarchais in France invented plots and characters that commented sharply on the class system, but few of the modern plots had the topical appeal of the old Spanish legend of aristocratic privilege abused and punished. Mozart and da Ponte, who may have had only a vague awareness of developments in France, England and America but were certainly conscious of democratic agitation in Central Europe, found a myth ready to hand and used it.

One striking feature of their Don Giovanni is the serious musical treatment that Mozart gives to da Ponte's simple text, 'Viva la Libertà!,' in 
scene 22 of Act I. Don Giovanni seems simply to be welcoming some guests to his masked ball with a formulaic greeting: 'This is Liberty Hall ['E $\mathrm{E}$ aperto a tutti quanti']: long live freedom!' Yet suddenly the music is as grandiose as late symphonic Beethoven ('Es lebe die Freiheit,' reads the German text). The portentous trumpet-and-kettle-drum cadence is repeated several times, both by Giovanni and a tutti of maskers. The effect is startling; clearly (and characteristically) Mozart saw more in this passage than meets the casual eye. His treatment goes to the centre, not only of his own protagonist, but of the Don Juans of the previous two centuries. For by this point in the opera (and in the tradition) the 'liberta' ironically invoked by Don Giovanni can be understood as comprising the full range of meanings from Liberty Hall to libertinage, 'freedom in love and in morality, ${ }^{21}$ all of the 'freedoms' that he wants and takes. Not the least of the ironies here is that Donna Elvira, Donna Anna and Don Ottavio are up there warbling away in praise of libertà with the old rake they have come to expose.

This Don Giovanni, the last of the ancien régime, is appropriately old and used up; he may toast liberty but he will not take liberties again. Ideologically da Ponte's text has much in common with Molière's: libertinism is connected with social disorder, and much of the comic interest attaches to the servant, now called Leporello, who, like Sganarelle, gets the first as well as the last word. His opening complaint could have been given broad application to the plight of the common man in 1787:

\author{
Notte e gioron faticar \\ per chi nulla sa gradir \\ pioggia e vento sopportar \\ mangiar male e mal dormir! \\ Slaving night and day \\ for one whom nothing pleases \\ enduring rain and wind, \\ eating and sleeping badly!
}

Mozart treated this as a fullscale aria, using as his refrain, 'Voglio fare il gentiluomo, / e non voglio più servir' ['I'd like to live the life of a gentleman and serve no more']. Here, finally, are the social fruits of libertinism such as Don Juan's: if the aristocrat will not accept limits to his freedom, why should his servant, or any common man? If noblesse n'oblige pas, a whole range of questions about the upper classes is opened up. It was a shrewdly mixed message for 1787 , both conservative - beware the abyss of anarchy - and mildly progressive: these 
irresponsible noblemen are sowing the whirlwind. This social dimension is not a substitute for the philosophical or existential reading of Don Juan, but an added level, a faithful reflection of the times. The nineteenth century would look into the Don Juan mirror and see something quite different: its selves, of course.

\section{RICHARD W. BEVIS}

University of British Columbia

\section{Notes}

1 G. B. Shaw, Preface to Man and Superman (Harmondsworth: Penguin, 1965), p. 10.

2 Giacomo Casanova, History of My Life, trans. Willard R. Trask (New York: Harcourt, Brace, 1966), p. 76.

3 For the references in this brief survey I am generally indebted to Leo Weinstein, The Metamorphoses of Don Juan (Stanford: Stanford University Press, 1959), an indispensable source for work on this subject.

4 Oscar Mandel, ed., Introduction to Three Classic Don Juan Plays (Lincoln: University of Nebraska Press, 1971), p. ix.

5 Tirso de Molina, El Burlador de Sevilla y el Convidado de Piedra (Madrid: Editora Internacional, 1924), p. 73.

6 Mandel, p. 50; Tirso, pp. 156-57.

7 John Fletcher, The Wild-Goose Chase, in Beaumont and Fletcher. Select Plays (London: Dent, 1962), pp. 325, 332, 318.

8 Quoted by Leslie Marchand, ed., in his Introduction to Lord Byron, Don Juan (Boston: Houghton Mifflin, 1958), p. ix.

9 Jean-Baptiste Molière, Dom Juan, in Oeuvres Complètes (n. p.: Librairie Gallimard, 1956), p. 809.

10 Weinstein, p. 30.

11 Molière, p. 801.

12 Mandel, p. 61; Molière, p. 779.

13 Molière, p. 809.

14 Mandel, p. 59; Molière, p. 777.

15 Thomas Shadwell, The Libertine, in The Complete Works of Thomas Shadwell, ed. Montague Summers, 5 vols. (London: Fortune Press, 1927), 3:28.

16 Shadwell, 3:43.

17 Shadwell, 3:56. 
18 Shadwell, 3:91.

19 See Weinstein, pp. 36-7.

20 Maximillian E. Novak, William Congreve (New York: G. K. Hall, 1971), p. 43.

21 Shaw, p. 11. 